Nippon Suisan Gakkaishi $\quad 81(3), 488$ (2015)

\title{
ミニシンポジウム記録＼cjkstart水産物におけるゲノム編集の現状と展望
}

\section{2. 水産・医薬モデルメダカの作出}

\author{
木下政人 \\ 京都大学大学院農学研究科
}

2. Generation of genome engineered medaka as a model for fisheries and medical science

MASATO KINOSHITA

Graduate School of Agriculture, Kyoto University, Sakyoku, Kyoto 606-8502, Japan

ゲノム編集技術によりモデル生物はもとより，非モデ ル生物を用いても任意の遺伝子の破壊やゲノム上の任意 の部位での遺伝子の書き換え・外来遺伝子の導入が可能 となった。既に複数の魚種でもゲノム編集の有効性が報 告されている。1-3) 本発表では，ゲノム編集技術を用い た, 水産学 (水産業) や医学・創薬へのメダカの応用に ついて話題提供する。

\section{1. 水産への応用}

魚類に打けるゲノム編集技術では，TALEN ゃ CRISPR/Cas9 などの RNA を受精後間もない卵にマイ クロインジェクション法などで導入することが一般的で あり，設計した TALEN やガイド RNAの有効性を評価 するには, 少なくとも数日を必要とする。しかし, 養殖 魚の産卵期間は限られ，その期間内に多くの TALEN やガイド RNA を評価することは困難であり，また，成 魚までの生育に長期間を要し, 狙った遺伝子の破壊の評 価にも長期間を必要とする。一方メダカは毎日周年産卵 するため受精卵の確保が容易で，一世代期間も数ヶ月と 短い。養殖魚に用いる TALEN やガイド RNAの効率的 な設計と選抜に，このようなメダカの利点の活用を試み ている。これまでに，マダイ，トラフグおよびメダカを 用いて，ゲノム上の相同な配列をターゲットに CRISPR/Cas9 システムを用いて遺伝子破壊を行ったと ころ，遺伝子破壊が誘導され易い，めるいは，誘導され 難い部位がこの 3 魚種において共通することが見いた された。また，標的となる遺伝子を破壊した場合の表現 型や二次的効果（副作用的効果）を短期間で見極めるこ とが可能なこともメダカの利点である。このようにメダ
力を使って養殖魚の限られた産卵期間を有効に使うこと が可能となると考えられる。

\section{2. 医薬への応用}

ゲノム解読の進展, 低コスト, ハイスループットが可 能なこと等から小型魚類が医学・創薬の分野でもモデル 生物として注目されている。メダカやゼブラフィッシュ では，これまでに疾患原因遺伝子過唾発現型ヒト疾患乇 デル, ${ }^{4)}$ あるいは TILLING 法を用いた遺伝子破壊型ヒ ト疾患モデル5)が作製されてきた。ゲノム編集技術によ り，より簡便に遺伝子を破壊することが可能となり，今 後小型魚類を用いたヒト疾患モデルの作製がますます盛 んになると考えられる。一例として，これまで単一の遺 伝子を破壊することでは思うようなヒト疾患モデルにな り得なかったものに，ゲノム編集技術を用い容易に他の 遺伝子破壊を付加できる。つまり，複数の TALEN たは CRISPR/Cas9 を一度に用いて複数の遺伝子破壊を 行なうことが可能となり, あるいは, 既存の遺伝子破壊 系統や過㮃発現系統に新たな遺伝子破壊を誘導すること が容易になった。ヒト疾患モデルメダカの作製やそれを もとにした疾患メカニズムの解明・治療薬の開発が進ん でいくと考えられる。

\section{文献}

1) Ansai S, Kinoshita M. Targeted mutagenesis using CRISPR/Cas system in medaka. Biology Open. 2014; 3: 362-371.

2) Hwang WY, Fu Y, Reyon D, Maeder ML, Tsai SQ, Sander JD, Peterson RT, Yeh JR, Joung JK. Efficient genome editing in zebrafish using a CRISPR-Cas system. Nature Biotechnology. 2013; 31: 227-229.

3) Edvardsen RB, Leininger S, Kleppe L, Skaftnesmo KO, Wargelius A. Targeted mutagenesis in Atlantic salmon (Salmo salar L.) using the CRISPR/Cas9 system induces complete knockout individuals in the F0 generation. PLoS One. 2014; 9: e108622.

4) Xi Y, Noble S, Ekker M. Modeling neurogeneration in zebrafish. Curr. Neurol. Neurosci. Rep. 2011; 11: 274-282.

5) Matsui $H$, Gavinio $R$, Asano $T$, Uemura $N$, Ito $H$, Taniguchi Y, Kobayashi Y, Maki T, Shen J, Takeda S, Uemura K, Yamakado H, Takahashi R. PINK1 and Parkin complementarily protect dopaminergic neurons in vertebrates. Hum. Mol. Genet. 2013; 22: 2423-2434. 